\title{
Water-bears from the Rocky Mountains: A First Look at Alberta's Tardigrade Fauna
}

\author{
Matthew J. Boeckner and Heather C. Proctor
}

Department of Biological Sciences, University of Alberta, Edmonton, Alberta T6G 2E9 Canada; email: Boeckner@ualberta.ca

Boeckner, Matthew J., and Heather C. Proctor. 2005. Water-bears from the Rocky Mountains: A first look at Alberta's: tardigrade fauna. Canadian Field-Naturalist 119(4): 586-588.

There is no information in the published literature regarding Alberta's terrestrial water-bear (Tardigrada) fauna. We surveyed across an elevational gradient $(1100-1800 \mathrm{ft})$ on Black Cat Mountain in the Alberta Rocky Mountain range. Ten taxa were identified from 902 specimens, all of which are new records for Alberta and one species is new for Canada: Macrobiotus cf. islandicus Richters, 1904. There was no clear relationship between elevation and tardigrade distribution, possibly owing to patchiness of these animals in the field and lack of adequate replication at each elevation.

Key Words: Tardigrada, elevation diversity, faunistic survey, Black Cat Mountain, Alberta.

Given the charismatic nature of water-bears (Tardigrada) and relative ease of collection, it is remarkable that so little is known about the ecology of Canadian tardigrades (see Boeckner et al. 2005 for a review of studies on Canadian tardigrades). Species lists exist for some Canadian provinces and territories; however, most records were compiled during patchy trans-Canadian surveys conducted in the early $20^{\text {th }}$ century (Richters 1908; Murray 1910). British Columbia, Newfoundland and Labrador, New Brunswick, the Yukon and Northwest Territories have had the largest number of studies, British Columbia leading with five (Boeckner et al., 2005). Alberta, Manitoba, Nova Scotia and Prince Edward Island currently have no records of terrestrial tardigrades; however, a single study identified members of the genus Hypsibius in five Albertan lakes (Anderson and DeHenau 1980). Also, Murray (1910) collected tardigrades from the Rocky Mountains; however, it is unclear whether these samples were from Alberta or British Columbia.

The aim of this study was to begin the first of many forays that will result in a comprehensive list of Albertan tardigrade fauna. Additionally, elevation has been investigated as a factor affecting tardigrade assemblages (example: Guidetti et al. 1999). Thus, our data also provide information regarding distribution patterns across an elevational gradient.

\section{Materials and Methods}

The study was conducted on Black Cat Mountain (Figure 1) in the Rocky Mountain Foothills (Boule Range) east of Jasper National Park $\left(53^{\circ} 18^{\prime} \mathrm{N}\right.$ : $\left.117^{\circ} 52^{\prime} \mathrm{W}\right)$. Moss samples ( $250 \mathrm{ml}$ each) were collected from eight sites along an elevational gradient. The lowest altitude sampled was $1100 \mathrm{~m}$, the highest was $1800 \mathrm{~m}$ and samples in between were collected at altitudinal intervals of $100 \mathrm{~m}$. The moss collected was Pleurozium schreberi (Brid.) Mitt., which is a widespread species common in dry forested areas (Johnson et al. 1995). Two sub-samples were collected at each altitude. Each of the 16 samples was placed in a separate paper bag for transport from the field.
Tardigrade extraction from the moss was achieved by using a Baermann funnel apparatus (Whitehead and Hemming 1965). This involved placing a sample of moss wrapped in cheesecloth in the cone of a blocked funnel. The funnel was then filled with water to submerge the sample. Live tardigrades migrate through the cheesecloth and collect in the water at the narrow base of the funnel. After 48 hours, the water from the base of the funnel was collected by removing the stopper. Any tardigrades remaining in the moss were separated by agitating the sample repeatedly in water. The water from both of these techniques was then combined and examined under a stereomicroscope (minimum 25x) for tardigrades and their eggs. Specimens were slidemounted using polyvinyl alcohol medium (commercially available as PVA from BioQuip Products Inc., catalogue number 6371).

Identification of species was facilitated using the work of Ramazzotti and Maucci (1983). Hieronim Dastych (Zoologisches Institut und Zoologisches Museum, Universitaet Hamburg) and Nigel Marley (Faculty of Science, University of Plymouth) provided invaluable assistance by confirming the identities of voucher specimens.

\section{Results}

A total of 902 tardigrades representing seven genera and nine identifiable species were extracted from the 16 moss samples. Eighty-seven specimens were in poor condition and unidentifiable. Six of the species identified in this study (denoted by cf.) were from complexes composed of very similar sub-species (H. Dastych, personal communication). Tardigrade eggs are often required to identify sub-species within a complex. The tardigrades found in the greatest abundance were Ramazzottius sp. ( $\mathrm{N}=247)$, Macrobiotus cf. hufelandi Biserov, $1991(\mathrm{~N}=154)$, Macrobiotus cf. richtersi Murray, $1911(\mathrm{~N}=107)$ and Milnesium tardigradum Doyere, $1840(\mathrm{~N}=100)$. The Ramazzottius sp. may represent more than one species; however, without eggs this could not be determined. The remaining species were each represented by fewer than 100 specimens: 
Hypsibius cf. convergens Urbanowicz, 1925 ( $\mathrm{N}=79)$, Macrobiotus cf. areolatus Murray, 1907 ( N=66), Macrobiotus cf. islandicus Richters, $1904(\mathrm{~N}=29)$, Echiniscus spitsbergensis Scourfield, $1987(\mathrm{~N}=23)$, Isohypsibius cf. tuberculatus Plate, $1888(\mathrm{~N}=8)$ and Platycrista cheleusis Kathman, $1990(\mathrm{~N}=2)$.

All 10 taxa are new records for Alberta. One species was a new record for Canada (McInnes 1994; Boeckner et al., 2005): $M$. cf. islandicus. Platicrista cheleusis has only ever been recorded previously in British Columbia (Kathman 1990). Table 1 shows the distribution patterns of the nine tardigrades identified to species and locations in Canada where they have been previously recorded.

An analysis of the distribution of species across an altitudinal gradient revealed only a few minor patterns. The third $(1300 \mathrm{~m})$ and fifth $(1500 \mathrm{~m})$ elevations contained the majority of specimens, $41 \%$ and $32 \%$, respectively. Within these two altitudes Ramazzottius sp. dominated but was not found again within the other elevations. Milnesium tardigradum was relatively abundant in the third elevation but was not recorded elsewhere. Similarly, $M$. cf. islandicus and the one heterotardigrade identified, E. spitsbergensis, were found only in the lower elevations (1100 to $1300 \mathrm{~m}$ ). M. cf. hufelandi exhibited the most even distribution across the gradient.

\section{Discussion}

All 10 of the tardigrade taxa identified within this study were new records for Alberta and one species was a new record for Canada. The discovery of $M$. cf. islandicus was surprising given the limited distribution of this species reported in previous studies (Table 1). Ramazzotti and Maucci (1983) describe this species as neither frequently found nor hard to find suggesting that it may have a widespread distribution but generally low abundance. Platycrista cheleusis has previously found only on Vancouver Island, British Columbia (Kathman 1990). The remaining seven species are

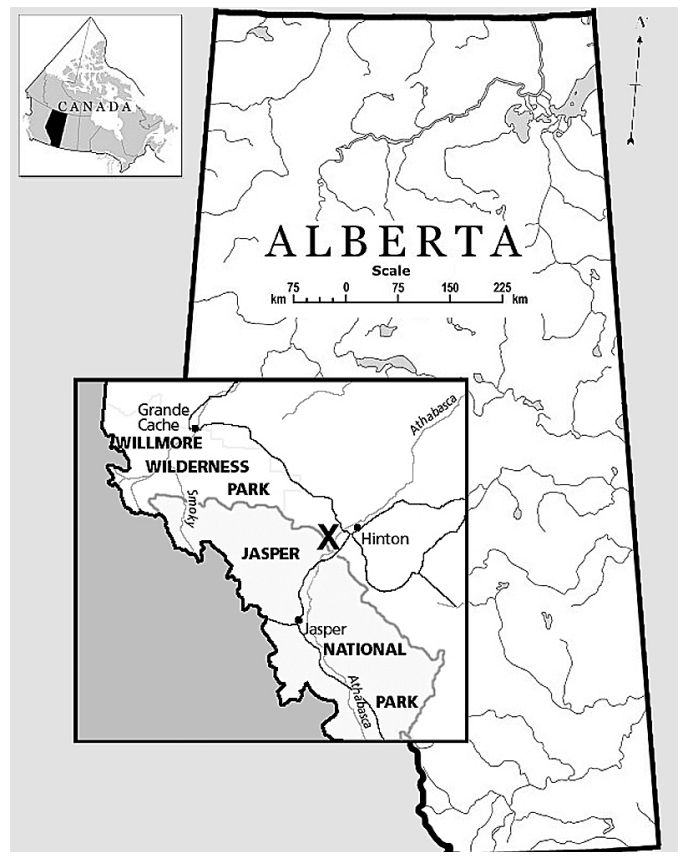

FIGURE 1. Location of Black Cat Mountain (X) in the Rocky Mountain foothills just outside of Jasper National Park.

reported to have widespread to cosmopolitan distributions and therefore it is not surprising to identify them from Alberta mosses. It is important to note that although species designations are given here for most taxa, the lack of tardigrade eggs within the samples made some identification possible only to complexes of sub-species (denoted by cf.). Voucher specimens of each species were submitted to the University of Alberta freshwater invertebrate collection and are available upon request.

Table 1. Nine species of tardigrades new to Alberta and where previously recorded in Canada (adapted with permission from Bateman and Collins 2001). Distribution patterns as noted by Ramazzotti and Maucci (1983) and McInnes (1994). Locations: BC, British Columbia; L, Labrador; NB, New Brunswick; NF, Insular Newfoundland; NWT, Northwest Territories; ON, Ontario; PQ, Province du Quebec. Recorded by: A, Argue (1971, 1972, 1974); B\&C, Bateman and Collins (2001); B, Boeckner et. al. (2005); I, Iharos (1973); K, Kathman (1990); M, Murray (1910); P, Pilato (1977); R, Richters (1908); VR ${ }^{1}$, Van Rompu et al. (1991); VR², Van Rompu et al. (1992).

\begin{tabular}{lll}
\hline \hline \multicolumn{1}{c}{ Species } & Canadian Records & Distribution \\
\hline Echiniscus spitsbergensis & $\mathrm{NB}(\mathrm{A}), \mathrm{NWT}\left(\mathrm{VR}^{1,2}\right)$ & widespread \\
Macrobiotus cf. areolatus & $\mathrm{BC}(\mathrm{M}, \mathrm{K}), \mathrm{NB}(\mathrm{A}), \mathrm{ON}(\mathrm{M}), \mathrm{RM}(\mathrm{M}), \mathrm{SK}(\mathrm{P})$ & cosmopolitan \\
$M$. cf. hufelandi & $\mathrm{BC}(\mathrm{R}, \mathrm{M}, \mathrm{K}), \mathrm{L}(\mathrm{B}), \mathrm{NB}(\mathrm{A}), \mathrm{NF}(\mathrm{B} \& \mathrm{C}), \mathrm{ON}(\mathrm{M}), \mathrm{PQ}(\mathrm{I}), \mathrm{RM}(\mathrm{M})$ & cosmopolitan \\
M. cf. islandicus & new Canadian record & Europe-Iceland \\
$M$. cf. richtersi & $\mathrm{BC}(\mathrm{K}), \mathrm{NB}(\mathrm{A}), \mathrm{PQ}(\mathrm{I})$, & cosmopolitan \\
Hypsibius cf. convergens & $\mathrm{BC}(\mathrm{K}), \mathrm{L}(\mathrm{B}), \mathrm{NB}(\mathrm{A}), \mathrm{NF}(\mathrm{B} \& \mathrm{C}), \mathrm{NWT}\left(\mathrm{VR}^{1,2}\right)$ & cosmopolitan \\
Isohypsibius cf. tuberculatus & $\mathrm{BC}(\mathrm{M}), \mathrm{NB}(\mathrm{A})$ & widespread \\
Platycrista cheleusis & $\mathrm{BC}(\mathrm{K})$ & Canada-BC \\
Milnesium tardigradum & $\mathrm{BC}(\mathrm{R}, \mathrm{K}), \mathrm{L}(\mathrm{B}), \mathrm{NB}(\mathrm{A}), \mathrm{NF}(\mathrm{B} \& \mathrm{C}), \mathrm{ON}(\mathrm{M}), \mathrm{PQ}(\mathrm{I})$ & cosmopolitan \\
\hline \hline
\end{tabular}


The analysis of tardigrade distributions across an elevational gradient produced only weak patterns. This was likely owing to lack of adequate replication at each elevation and natural variation in tardigrade abundance and distribution (patchiness). Furthermore, sample sites were likely variable in more ways than elevation alone (i.e., exposure, substrate type, moisture, etc.). Generally, $M$. cf. hufelandi tended to have a more uniform distribution throughout most elevations when compared with the other species. Additionally, Echiniscus spitsbergensis and $M$. cf. islandicus had distributions limited to lower elevations. It remains to be determined whether these general trends are indicative of actual altitude-constrained distributions.

Although this study has identified a fair number of Albertan tardigrades there are vast areas of the province that have yet to be surveyed. Until such investigations are made it is impossible to comment confidently on species ranges.

\section{Acknowledgments}

We thank Hieronim Dastych and Nigel Marley for lending their outstanding expertise in tardigrade identification to this study. Much appreciation is also extended to Kevin McEwan and Danica Belter who aided in collection and extraction of the samples. We gratefully acknowledge the financial support of this research by the Natural Sciences and Engineering Research Council Discovery Grant held by Heather C. Proctor.

\section{Literature Cited}

Anderson, R., and A. DeHenau. 1980. An assessment of the meiobenthos from nine mountain lakes in western Canada. Hydrobiologia 70: 257-264.

Argue, C. W. 1971. Some terrestrial tardigrades from New Brunswick, Canada. Canadian Journal of Zoology 49: 401415.

Argue, C. W. 1972. Tardigrades from New Brunswick, Canada 2. Canadian Journal of Zoology 50: 87-94.

Argue, C. W. 1974. Tardigrades from New Brunswick, Canada 3. Canadian Journal of Zoology 52: 919-922.

Bateman, L. E., and M. Collins. 2001. A preliminary account of the tardigrades of Newfoundland. Zoologischer Anzeiger 240: $223-232$
Boeckner, M., M. Collins, J. Finney-Crawley, and L. Bateman. In press. The bryofauna of remote coastal Labrador: including a review of current Canadian records. Zootaxa*.

Guidetti, R., R. Bertolani, and D. R. Nelson. 1999. Ecological and faunistic studies on tardigrades in leaf litter of beech forests. Zoologischer Anzeiger, 238: 215-223.

Iharos, G. 1973. Angaben zur geographischen Verbreitung der Tardigraden. Opuscula Zoologica (Budapest) 12: 7386.

Pilato, G. 1977. Macrobiotus willardi, a new species of tardigrada from Canada. Canadian Journal of Zoology 55: 628-630.

Johnson, D., L. Kershaw, A. MacKinnon, and J. Pojar. 1995. Plants of the western boreal forest and aspen parkland. Lone Pine Publishing and the Canadian Forest Service. Alberta, Canada.

Kathman, R. D. 1990. Eutardigrada from Vancouver Island, British Columbia, Canada, including a description of Platicrista chilensis n. sp. Canadian Journal of Zoology 68: 1880-1895.

McInnes, S. J. 1994. Zoogeographic distribution of terrestrial/freshwater tardigrades from current literature. Journal of Natural History 28: 257-352.

Murray, J. 1910. Tardigrada of the British Antarctic Expedition 1907-1909. London. 1: 81-185.

Ramazzotti, G., and W. Maucci. 1983. The Phylum Tardigrada. Memorie dell'Instituto Italiano di Idrobiologia 41: 1-1012.

Richters, F. 1908. Beitrag zur kenntis der moosfauna Australiens und der Inseln des Pazifishcen Ozeans. Zoologische Jahrbuecher Abteilung fuer Systematik Oekologie und Geographie der Tiere 26: 196-213.

Van Rompu, E. A., W. H. de Smet, and J. M. Bafort. 1991. Contributions to the Tardigrada of the Canadian High Arctic. 2. Fresh water tardigrades from Little Cornwallis Island, Northwest Territories, Canada. Biologisch Jaarboek Dodonaea 59: 132-140.

Van Rompu, E. A., W. H. de Smet, and L. Beyens. 1992. Contributions to the Tardigrada of the Canadian High Arctic. 1. Freshwater Tardigrades from Devon Island, Northwest Territories, Canada. Canadian Field-Naturalist 106: 303-310.

Whitehead, A. G., and J. R. Hemming. 1965. A comparison of some methods of extracting small vermiform nematodes from soil. Annals of Applied Biology 55: 25-38.

Received 15 August 2004

Accepted 14 November 2005

*added in proof 2006 1105: 1-16 